\title{
DESAIN PEMBELAJARAN MATEMATIKA DENGAN KONTEKS PERMAINAN KULI BIA \\ PADA MATERI FAKTOR PERSEKUTUAN TERBESAR \\ DAN KELIPATAN PERSEKUTUAN TERKECIL
}

Oleh: Emy Sohilait ${ }^{1 *}$, Yahya Lamasano ${ }^{2}$

1 Program Studi Pendidikan Matematika, STKIP Gotong Royong Masohi, J1 Trans Seram Belakang

Negeri haruru, Maluku Tengah, 97514 Indonesia

2 Program Studi Pendidikan Bahasa dan Sastra Indonesia, STKIP Gotong Royong Masohi, J1 Trans

Seram Belakang Negeri haruru, Maluku Tengah, 97514 Indonesia

${ }^{*}$ Corresponding author, e-mail: sohilaitemy@gmail.com

\begin{tabular}{ll}
\hline & Abstract \\
\hline Keyword: & The learning process of the concept of greatest and Least which \\
are the prerequisites of the greatest common divisor and the least \\
common multiple in class IV SD Inpres 2 Waipo is carried out \\
education; kuli bia; & with the teaching paradigm that is, using T tables, multiples, and \\
hypothetical learning & not using student thought conjectors in find concepts or material. \\
trajectory; learning & This underlies researchers to design learning designs using \\
trajectory; effective. & Realistic Mathematics Education (RME) with the context of the \\
& kuli bia game as a starting point. The purpose of this study is to \\
produce a learning trajectory and determine the impact of the use \\
of learning designs on the mathematical knowledge construction \\
process. Design research was chosen to achieve this goal which \\
consists of three stages: preliminary design, teaching \\
experiment, retrospective analysis. The results of the study \\
found that the kuli bia game provides an important role in \\
supporting learning and increases learning motivation, able to \\
understand the material based on the learning trajectories \\
generated, provides a variety of strategies in solving problems \\
both at the situational stage, models of, models for and formal \\
stages, the implementation of RME with the context of the kuli \\
bia game on the material is running optimally, the response of \\
students and teachers is positive and effective management of \\
learning in the classroom.
\end{tabular}

\section{Pendahuluan}

Pembelajaran Matematika Realistik (PMR) menawarkan suatu proses pembelajaran secara bertahap mulai dari konsep yang sederhana menuju pada konsep yang lebih kompleks. Rangkaian proses ini menghasilkan learning trajectory (lintasan belajar) setelah dilakukan proses pembelajaran. Agar learning trajectory ini dapat muncul dalam pembelajaran, maka guru harus bisa merumuskan suatu antisipasi didaktis pedagogis melalui dugaan lintasan belajar atau Hypothetical Learning Trajectory (HLT) (Daro et al., 2011). HLT terdiri atas tiga kompenen utama yaitu : (1) tujuan pembelajaran (learning goals), (2) aktivitas pembelajaran (learning activities) (3) dugaan proses belajar siswa (hypothetical learning process).

HLT dapat dilakukan melalui analisis terhadap hambatan-hambatan belajar (learning obstacles) yang dihadapi oleh siswa sehingga penyebab kesulitan siswa dapat diantisipasi atau bahkan dihindari. Pentingnya HLT (Wijaya, 2009, p. 374) dianalogikan dengan perencanaan rute perjalanan. Jika kita memahami rute-rute yang mungkin untuk menuju tujuan, maka bisa memilih rute yang mungkin untuk mencapai 
tujuan. Selain itu, kita juga bisa menyelesaikan permasalahan yang kita hadapi dalam perjalanan jika kita paham rute tersebut.

Berbagai penelitian telah dilakukan oleh para ahli mengenai hypothetical learning trajectory, antara lain (Bakker et al., 2003, p. 15) yang berhasil merumuskan sebuah hypothetical learning trajectory yang dapat digunakan agar teknologi informasi dapat menunjang pengembangan simbol dan maknanya dalam pendidikan matematika, khususnya pada materi pokok statistik. (Bardsley, 2006, p. 14) dalam disertasinya yang berjudul 'Pre-Kindergarten Teachers' Use and Understanding of Hypothetical Learning Trajectoriesin Mathematics Education", berhasil merumuskan sebuah alur belajar yang dapat digunakan dalam mengajarkan matematika untuk anak pra sekolah. (Hadi, 2006, p. 8), dalam tulisannya Adapting European Curriculum Material for Indonesian Schools, merumuskan sebuah alur belajar hipotetik, untuk pembelajaran materi pecahan disekolah dasar. Pada alur tersebut digambarkan dengan jelas urutan aktivitasaktivitas belajar yang akan berlangsung dan tujuan yang akan dicapai pada setiap langkah tersebut. Pada alur belajar tersebut tergambar tentang urutan pembelajaran (learning sequence), yang harus dilalui, serta konsep yang akan dipelajari pada setiap langkah. Dari beberapa penelitian tentang learning trajectory di atas semuanya terkait dengan pembelajaran di kelas. HLT merujuk pada rencana pembelajaran berdasarkan antisipasi belajar siswa yang mungkin dicapai dalam proses pembelajaran yang didasari pada tujuan pembelajaran matematika yang diharapkan pada siswa, pengetahuan, dan perkiraan tingkat pemahaman siswa, serta pilihan aktivitas matematika secara berurut (Fuadiah, 2017, p. 1). Dengan demikian, tugas guru adalah membuat suatu desain didaktis pembelajaran yang bisa memberikan antisipasi didaktis pedagogis sehingga suatu topik pembelajaran bisa disampaikan sesuai dengan karakteristik serta tujuan yang ingin dicapai.

Hasil observasi dengan guru kelas IV SD Inpres 2 Waipo, peneliti mendapatkan informasi bahwa proses pembelajaran konsep faktor dan kelipatan yang merupakan prasyarat materi Faktor Persekutuan terBesar (FPB) dan Kelipatan Persekutuan terKecil (KPK) dilakukan dengan paradigma mengajar yakni, menggunakan tabel $\mathrm{T}$ untuk mencari faktor suatu bilangan, sedangkan cara mengajarkan topik kelipatan sama dengan cara mengajarkan topik bilangan loncat yaitu langsung menuliskan bilangan loncat. Pembelajaran ini sesuai dengan paradigma mengajar karena matematika diajarkan sebagai produk jadi, siswa juga menerima pengetahuan secara pasif dan tidak menggunakan strategi pemikiran siswa. Selain itu, guru belum menggunakan permainan yang mengajak siswa untuk lebih memahami konsep faktor dan kelipatan.

Anak-anak pada umunya sangat suka bermain sebelum dan saat mereka mulai memasuki sekolah formal. Aktivitas bermain yang paling dominan terjadi ketika anak beradadi rumah misalnya bermain game, menyusun puzzle, bermain kuli bia, berolahraga dan sebagainya. Dengan demikian, ketika anak ke sekolah, mereka telah memiliki pengalamanpengalaman yang tidak mereka sadari sebagai pengalaman informal matematika.

(Haylock \& Thangata, 2007, p. 139) menyatakan bahwa penggunaan aktivitas bermain dalam pembelajaran matematika dapat membantu anak untuk memandang matematika sebagai pelajaran yang menyenangkan, bersifat sosial dan banyak berguna dalam kehidupan. Penggunaan beragam permainan diawal pembelajaran matematika akan membuat siswa senang untuk belajar matematika. Selain itu, dalam kegiatan bermain, akan terjadi interaksi sosial antara siswa. Dari interaksi ini diharapkan dapat ditemukannya suatu konsep matematika yang saling berkaitan (intertwining).

Permainan kuli bia merupakan permainan tradisional yang dimainkan oleh anak-anak di Maluku Tengah (Waipo) dengan menggunakan bola kasti dan cangkang kerang jenis Monetaria Annulus. Dalam permainan ini hanya sedikit orang yang mengetahui bahwa terdapat beberapa konsep matematika didalamnya. Konsep matematika yang terdapat adalah konsep penjumlahan, pengurangan, pembagian, dan konsep perkalian. Agar aktivitas bermain dapat bermanfaat seperti yang disebutkan di atas, maka pemilihan jenis kegiatan bermain dalam pembelajaran matematika (Bito, 2016, p. 252) harus memenuhi syarat: (1) memiliki tujuan untuk pengembangan konsep matematika dan aktivitas tersebut menyenangkan bagi anak; (2) aktivitas bermain harus dengan konteks yang bermakna; (3) menuntut tanggungjawab siswa dan dapat diawasi; (4) dapat diulang, dipraktikan dan dikuasai oleh siswa.

Tucker (Bito, 2016, p. 252) berpendapat bahwa untuk mendukung pengembangan konsep matematika 
menggunakan aktivitas bermain dibutuhkan kualitas keterlibatan guru pada beberapa tingkatan. Keterlibatan guru dimulai dari perencanaan, menyediakan sumber daya yang diperlukan untuk menstimulasi peluang pembelajaran, atau melibatkan diri secara langsung dalam permainan (Haylock \& Thangata, 2007, p. 139).

Selama kegiatan bermain berlangsung, guru dapat memperkenalkan kosakata matematika serta menggiatkan dialog dan penalaran matematika (Haylock \& Thangata, 2007, p. 139). Lewis seperti yang dikutip Pound (Haylock \& Thangata, 2007, p. 139) meyatakan bahwa kualitas kegiatan bermain dapat memfasilitasi siswa berpeluang untuk membuat keputusan, membayangkan, menalar, memprediksi, merencanakan, mengujicoba berbagai strategi dan mencatat.

Dalam PMR, kegiatan bermain dapat dijadikan konteks pada tahap awal pengembangan konsep matematika. Posisi kegiatan bermain dapat dijadikan sebagai aktivitas paling awal (aktivitas situasional) dalam belajar matematika. Dari konteks ini,siswa akan melakukan matematika (menggunakan model) secara bertahap mulai dari model situasi (konkrit) pengetahuan matematika (model formal).

Gravemeijer (Bito, 2016, p. 252) menyebutkan, pada awalnya siswa mengembangkan model atau cara yang sesuai dengan pemahamannya. Model ini masih bersifat kontekstual dan khusus dari (model of) situasi masalah yang diberikan. Model inilah yang menjadi dasar untuk mengembangkan pengetahuan matematika formal. Setelah proses generalisasi dan formalisasi model tersebut secara bertahap diarahkan untuk menuju model untuk (model for) pemikiran matematika pada tingkat yang formal seperti yang tertera pada Gambar berikut.

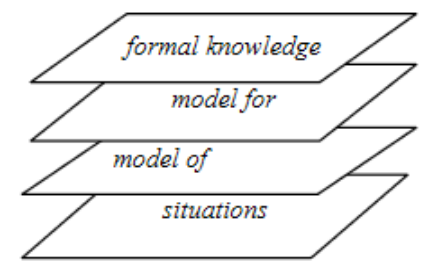

Gambar 1. Pengembangan model dalam PMR

Namun, yang perlu diketahui adalah bahwa siswa tidak menyadari bahwa kegiatan bermain yang sering mereka lakukan berhubungan dengan apa yang akan mereka pelajari. Oleh karena itu, butuh suatu aktivitas dimana guru menghubungkan pengalaman siswa secara matematis di kelas yang oleh Frans Morerlands (Sugiman, 2011, p. 9) dinamakan tahap orientasi lingkungan secara matematis.

Untuk menghubungkan kegiatan bermain dengan konsep yang akan dipelajari, orientasi kegiatan bermain secara matematis sangat penting. Pada tahap ini anak akan dibiasakan menyelesaikan masalah sehari-hari tanpa harus mengaitkan secara tergesa-gesa pada matematika formal. Anak akan memodelkan secara situasi permasalahan matematika yang berhubungan dengan konteks yang diberikan. Kegiatan matematis yang bersentuhan dengan berbagai konteks real yang menuju pada suatu konsep matematika akan menjadi landasan bagi siswa dalam tingkatan selanjutnya.

Dengan demikian peneliti akan mendesain dugaan lintasan belajar (Hypothetical Learning Trajectory)dengan pendekatan Pembelajaran Matematika Realistik menggunakan konteks bermain Kuli bia sebagai starting point pembelajaran yang berisi aktivitas-aktivitas untuk mendukung pembelajaran materi FPB dan KPK.

Rumusan masalah dalam penelitian ini adalah : (1) Bagaimana peranan permainan Kuli bia dalam memahami pembelajaran FPB dan KPK berdasarkan pendekatan PMR untuk siswa kelas IV SD Inpres 2 Waipo?; (2) Bagaimana lintasan belajar (Learning Trajectory) dalam memahami pembelajaran FPB dan KPK berdasarkan pendekatan PMR dengan konteks permainan Kuli bia berkembang dari tahap Informal ke tahap formal?; (3) Apakah implementasi PMR menggunakan konteks permaianan Kuli bia efektif?.

Tujuan penelitian ini adalah untuk (1) mengetahui peranan permainan Kuli bia dalam memahami pembelajaran FPB dan KPK berdasarkan pendekatan PMR untuk siswa kelas IV SD Inpres 2 Waipo, (2) menghasilkan lintasan belajar (Learning Trajectory) guna memahami materi FPB dan KPK berdasarkan pendekatan PMR dengan konteks permainan Kuli bia, (3) melihat dampak penggunaan desain pembelajaran terhadap proses konstruksi pengetahuan matematis siswa.

\section{Metode Penelitian}

Penelitian ini menggunakan metode design research. Gravemeijer dan Van Eerde (Surya et al., 2017, p. 151) metode penelitian yang bertujuan untuk mengembangkan Local 
Instruction theory (LIT) melalui kerjasama antara peneliti dan guru untuk meningkatkan kualitas pembelajaran melalui iterative analysis, mendesain atau memperbaiki design sebelumnya, dan melaksanakan pembelajaran dengan mengacu pada teori dan prinsip-prinsip realitas.

\section{Jenis Penelitian}

Penelitian ini menggunakan
pendekatan kualitatif.
Waktu dan Tempat Penelitian

Penelitian dilaksanakan pada tanggal 22 - 27 Juni 2020 dengan mengujicobakan HLT, perangkat pembelajaran, dan pemberian instrumen tes pada kelas IV SD Inpres 2 Waipo dengan proses pembelajaran luar jaringan (luring) dirumah.

\section{Target/Subjek Penelitian}

Subyek penelitian ini berjumlah 8 orang yang terdiri dari 6 siswa laki-laki dan 2 siswa perempuan.

\section{Prosedur}

Langkah-langkah yang dilakukan menurut Gravemeijer \& Cobb (Sohilait, 2019, p. 141) adalah :

1. Desain pendahuluan (preliminary design)

Pada tahap ini akan merancang dan melakukan validasi terhadap HLT dan perangkat pembelajaran. Dalam membuat HLT ini diperlukan kajian literatur (pendekatan PMR, permainan Kuli bia, pembelajaran FPB dan KPK pada tingkat SD) sebelum mendesain aktivitas pembelajaran, diskusi dengan guru yang berpengalaman, peneliti maupun ahli dalam bidang yang terkait. Sedangkan perangkat pembelajaran meliputi : rencana pelaksanaan pembelajaran (RPP), lembar kerja siswa (LKS).

$$
\begin{aligned}
& \text { 2. Ujicoba pembelajaran (teaching } \\
& \text { experiment) }
\end{aligned}
$$

Tahap ini bertujuan untuk mengumpulkan data yang akan digunakan untuk menjawab pertanyaan penelitian. Pada tahap ini, peneliti (guru model) mengujicobakan HLT non standard dan perangkat pembelajaran yang sudah divalidasi dan direvisi. Strategi atau pengalaman yang terjadi pada tahap ini akan menjadi dasar untuk mendesain ulang atau memodifikasi HLT

3. Analisis tinjauan (retrospective analysis)

Peneliti menganalisis data yang diperoleh dari tahap teaching experiment dan menggunakan hasil dari analisis untuk mengembangkan desain selanjutnya. HLT digunakan dalam tahap retrospective analysis sebagai panduan dan referensi utama dalam menjawab pertanyaan penelitian.
Adapun alur rancangan penelitian tiap siklusnya dengan menggunakan metode design research disajikan pada gambar berikut.

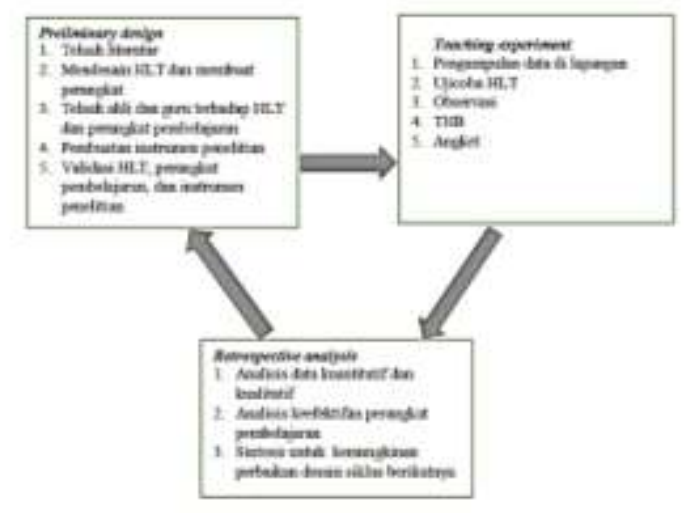

Gambar 2. Alur rancangan penelitian

\section{Data, Intrumen, dan Teknik Pengumpulan Data}

Dokumentasi digunakan untuk mengumpulkan hasil rekaman penelitian berupa foto dan video permainan Kuli bia kemudian dideskripsikan guna mengembangkan atau memperbaiki HLT yang telah didesain sebelumnya.

Observasi digunakan untuk mengumpulkan data aktivitas belajar siswa, aktivitas guru model dalam mengelola pembelajaran matematika realistik dengan konteks permainan Kuli bia. Data aktivitas siswa dan guru model dikumpulkan masingmasing dengan menggunakan lembar observasi.

Tes digunakan untuk mengumpulkan data nilai hasil belajar matematika siswa setelah proses pembelajaran.

Angket digunakan untuk mengumpulkan data respon siswa dan guru model terhadap pembelajaran menggunakan pembelajaran PMR dengan konteks permainan Kuli bia.

\section{Teknik Analisis Data}

HLT dibandingkan dengan tindakan proses pembelajaran yang dilakukan siswa sehingga dapat lakukan penyelidikan dan penjelasan bagaimana siswa memperoleh pemahaman tentang materi FPB dan KPK dari pembelajaran yang didesain.

Data aktivitas belajar siswa dan aktivitas pengelolaan pembelajaran oleh guru menggunakan pembelajaran matematika realistik dianalisis menggunakan lembar observasi aktivitas siswa dan lembar observasi aktivitas pengelolaan pembelajaran guru. Selain itu data tersebut dianalisis dari hasil rekaman video dan kamera. 
Data hasil belajar matematika siswa dianalisis untuk memperoleh informasi tentang kemampuan siswa terhadap materi pembelajaran.

Respon siswa dan guru terhadap pembelajaran dianalisis menggunakan hasil sebaran angket respon siswa dan guru terhadap pembelajaran matematika pada kategori senang, baru, berminat, jelas, atau tertarik, untuk setiap aspek yang direspon.

\section{Hasil Penelitian dan Pembahasan}

\section{Desain pendahuluan (preliminary design)}

a)Telaah ahli dan guru terhadap HLT serta perangkat pembelajaran. Pada tahap ini peneliti bersama dengan ahli PMR dan guru melakukan telaah terhadap HLT awal (non standart) dan perangkat pembelajaran. Dalam telaah HLT awal, peneliti, pakar PMR dan beberapa guru mitra melihat, mengamati dan mengecek kesesuaian dan kelayakan HLT dan perangkat dalam proses pembelajaran.

b) Mendesain HLT dan membuat perangkat. Dari hasil kajian literatur dan hasil analisis kurikulum ini maka dibuatlah draf desain pembelajaran serta perangkat pembelajaran yakni RPP, LKS yang kemudian didiskusikan dengan guru mata pelajaran dan dikembangkan lebih lanjut dengan analisis berdasarkan konjektur pemikiran siswa. Sehingga aktivitasaktivitas yang ada dalam desain pembelajaran ini, dapat benar-benar menuntun siswa dalam memahami materi FPB dan KPK dengan baik.

c) Pembuatan instrumen penelitian. Pada tahap ini peneliti membuat instrumen penelitian yaitu, soal tes untuk mengukur kemampuan kognitif, lembar observasi pengelolaan pembelajaran, lembar observasi aktivitas belajar siswa, angket respon guru dan angket respon siswa.

d) Validitas HLT, perangkat pembelajaran, dan instrumen penelitian. HLT, perangkat pembelajaran, instrumen yang telah dibuat kemudian divalidasi oleh ahli terkait validasi ini dan validasi konstruk. Hasil validasi pada HLT, disarankan bahwa menuliskan aturan permainan dan menambah aktivitas menemukan konsep Faktor dan Kelipatan formal dengan tujuan siswa mampu mencapai tujuan pembelajaran matematika formal. Validator menyarankan agar dalam RPP sebaiknya menguraikan aktivitas pembelajaran antara guru dan siswa, sehingga dapat terlihat dengan jelas interaksi antara guru dan siswa pada proses pembelajaran. Validator menyarankan pada LKS untuk menampilkan masalah yang relevan dengan kehidupan sehar-hari sehingga dapat mengkonstruksi pengetahuan matematis siswa. Sedangkan pada instrumen penelitian berupa THB disarankan agar memperhatikan indikator pembelajaran serta tingkatan soal yang diberikan. Hasil diskusi dengan mengikuti saran-saran serta petunjuk validator menjadi acuan peneliti dalam melakukan revisi. Berdasarkan hasil validasi isi dan konstruk diperoleh kriteria valid. Berikut ini merupakan gambar dari peneliti sedang melakukan uji validasi terhadap HLT, perangkat pembelajaran dan instrumen penelitian.

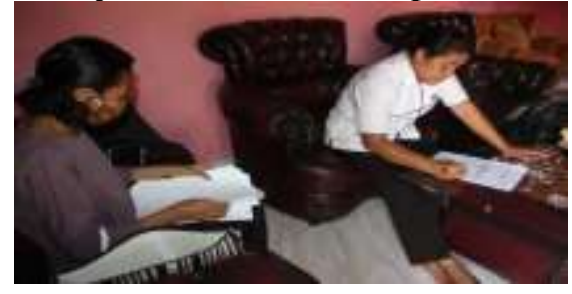

Gambar 3. Validasi ahli

\section{Ujicoba pembelajaran (teaching experiment)}

Teaching experiment bertujuan untuk mengimplementasikan HLT dan perangkat pembelajaran. Perangkat pembelajaran yang diujicoba adalah RPP, LKS dan instrumen penelitian yaitu tes hasil belajar, lembar observasi pengelolaan pembelajaran dan aktivitas siswa, angket respon guru dan siswa. Berdasarkan HLT hasil revisi, maka sebelum melakukan ujicoba pembelajaran peneliti (guru model) terlebih dahulu membuat aturan permainan Kuli bia dan disepakati bersama.

\section{Aktivitas 1 : bermain Kuli bia}

Proses pembelajaran matematika hari pertama diharapkan siswa dapat mengeksplorasi pengalaman siswa bermain Kuli bia dengan memperhatikan aturan-aturan yang disepakati. Cara bermain Kuli bia secara berkelompok dengan setiap kelompok terdiri dari 4 siswa (1 siswa perempuan dan 3 siswa laki-laki). Namun sebelumnya ada satu orang siswa yang secara suka rela melakukan simulasi bermain Kuli bia di depan. Setiap kelompok (apel dan anggur) bermain dengan jumlah yang berbeda yaitu 5, dan 6 biji cangkang untuk menyelesaikan LKS 1 . Guru model merancang 
demikian dengan tujuan terdapat keanekaragaman jawaban siswa sehingga mengurangi kemungkinan siswa mencontek pekerjaan kelompok siswa lain. Selain itu dengan adanya perbedaan jumlah biji cangkang tersebut, siswa dapat melihat banyak perbedaan sisa biji cangkang pada pengambilan terakhir dengan jumlah biji cangkang yang berbeda serta digenggam disetiap pengambilan jika siswa melakukan pengambilan satu-satu, duadua, dan tiga-tiga. LKS 2 semua (apel dan anggur) bermain dengan jumlah 6 biji cangkang. Peneliti merancang demikian karena mencegah kebingungan siswa dalam menentukan banyak biji cangkang yang digenggam. Berikut adalah gambar siswa yang sedang bermain Kuli bia .

Melalui aktivitas bermain yang dilakukan secara bergantian, siswa terlihat antusia dalam bermain. Dimana mereka melakukan pengambilan yang bersisa pengambilan yang tidak bersisa. Tetapi mereka belum menyadari terdapat konsep matematika yang terkandung dalam permainan tersebut.

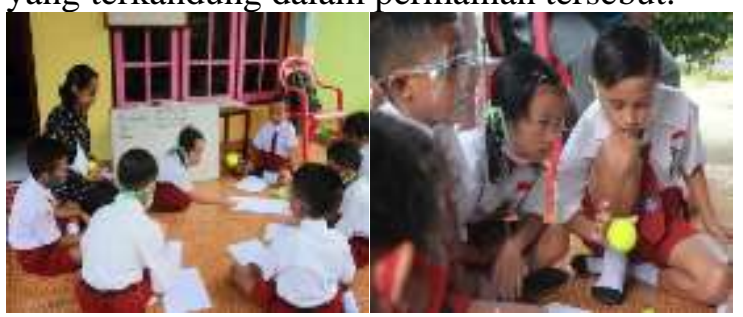

Gambar 4. Siswa bermain Kuli bia

Bentuk pemahaman siswa melalui pengalaman bermain Kuli bia dapat dilihat pada cuplikan wawancara guru dengan siswa sebagai berikut.

Guru : Hari ini katong akan belajar tapi sebelum itu katong barmaeng kamuka dolo. Sapa disini yang su pernah maeng Kuli bia?

Siswa : Beta sudah ibu, beta balong ibu (sambil berebutan menjawab)

Guru : sebelum bermain itu kan harus ada aturan to biar seng maeng paricu. Jadi katong biking aturan dolo.

Siswa : (sambil tertawa) iya ibu.

\section{Aktivitas 2 : menjawab soal diskusi}

Pada aktivitas hari kedua guru membagikan LKS yang terdiri dari 2 bentuk soal untuk diselesaikan. Siswa masih tetap berdiskusi kelompok seperti pada aktivitas sebelumnya. Siswa diingatkan kembali dengan melakukan pengambilan yang bersisa, tidak bersisa, pengambilan satu-satu, dua-dua, dan seterusnya. Diharapkan siswa dapat menemukan berbagai model sendiri (model of) untuk menentukan sisa dan biji cangkang yang digenggam. Dapat ditunjukan dengan gambar dibawah ini.
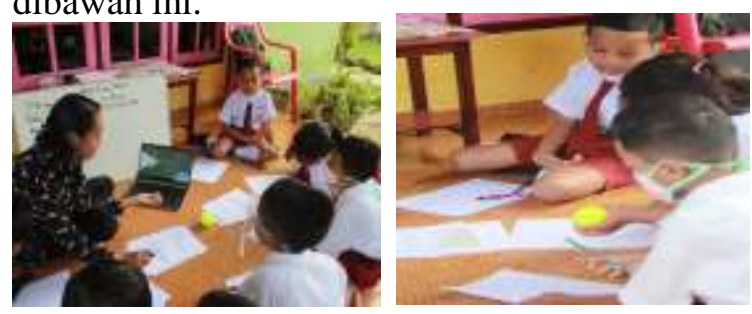

Gambar 5. Siswa menjawab soal diskusi

Selain bermain Kuli bia, mereka juga berdiskusi mengenai apa perbedaan sisa biji cangkang pada pengambilan terakhir saat siswa bekel diambil satu-satu, dua-dua dan tiga-tiga. Selama berdiskusi, terdapat beberapa strategi siswa yang muncul dalam menggambarkan bagaimana perbedaan sisa pengambilan terakhir pada setiap aturan pengambilan serta banyak biji cangkang yang digenggam di setiap urutan pengambilan pada aturan pengambilan satu-satu, dua-dua, tigatiga. Strategi atau model sendiri pada gambar 6 oleh kelompok Apel, peneliti mempelajari bahwa permainan Kuli bia dapat menstimulasi siswa untuk membuat cerita tentang pengamatan yang dilakukan pada berapa saja sisa biji cangkang pada setiap pengambilan serta berapa saja biji cangkang yang tersisa pada pengambilan terakhir. Cerita tersebut dapat menjadi modal siswa untuk menemukan konsep matematika pada permainan Kuli bia tersebut atau merumuskan bentuk yang lebih formal untuk menggambarkan berapa biji cangkang yang tersisa pada pengambilan terakhir.

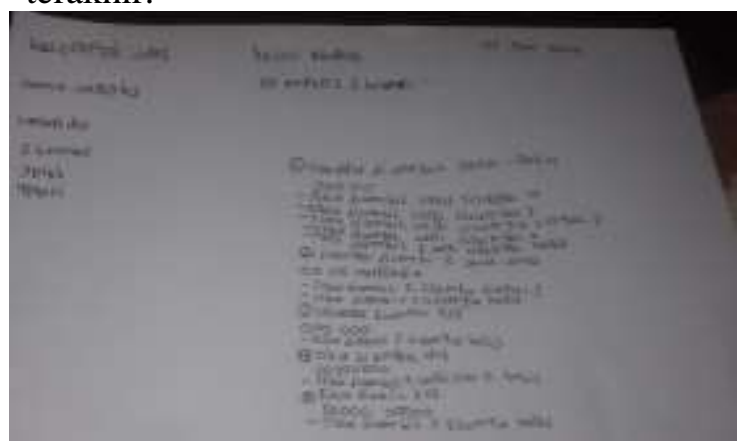

Gambar 6. Strategi kelompok apel menjawab soal LKS 1

Kelompok anggur pada gambar 7 menunjukan strategi dengan proses berpikir yang paling tinggi dengan menggambarkan sisa biji cangkang diambil dengan cara pengurangan berulang. Peneliti mengatakan demikian karena dalam strategi tersebut siswa sudah dapat menghubungkan konsep pengurangan secara 
formal dengan pengambilan yang dilakukan dalam permainan Kuli bia.

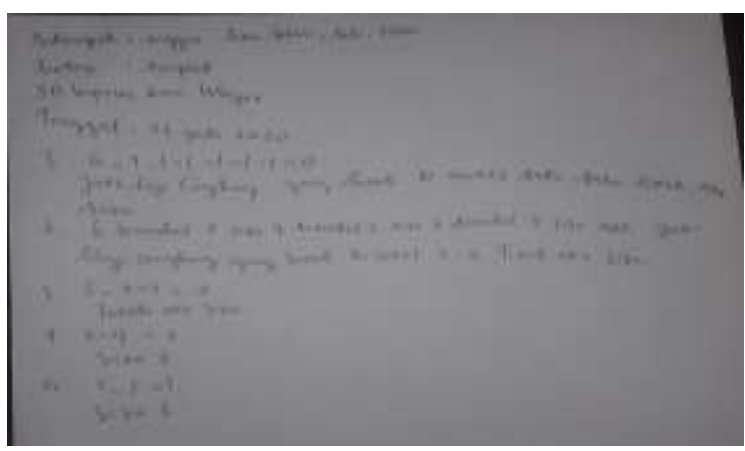

Gambar 7. Strategi kelompok anggur menjawab soal LKS 1

Siswa juga mendiskusikan bagaimana cara menggambarkan banyak biji cangkang yang digenggam disetiap pengambilan. Gambar 8 dan 9 memperlihatkan bahwa hasil kerja siswa kelompok anggur dan apel masih menceritakan banyak biji cangkang yang tersisa di setiap pengambilan pada aturan pengambilan satu-satu serta menggunakan pengurangan berulang untuk menentukan sisa biji cangkang pada pengambilan terakhir. Dengan demikian, peneliti menyatakan bahwa siswa belum memahami apa yang harus diamati (gambar 8 dan 9 pada lingkaran merah adalah jawaban yang keliru). Untuk membantu siswa memahami tentang objek yang diamati, guru dan peneliti memberikan ilustrasi kepada kelompok tersebut. Ilustrasi tersebut diberikan dengan cara mempraktekkan permainan Kuli bia serta menanyakan kepada kelompok tentang jumlah biji cangkang yang digenggam di setiap pengambilan. Dengan ilustrasi tersebut, siswa mulai memahami tentang objek yang diamati. Kemudian siswa pun mulai berdiskusi kelompok.

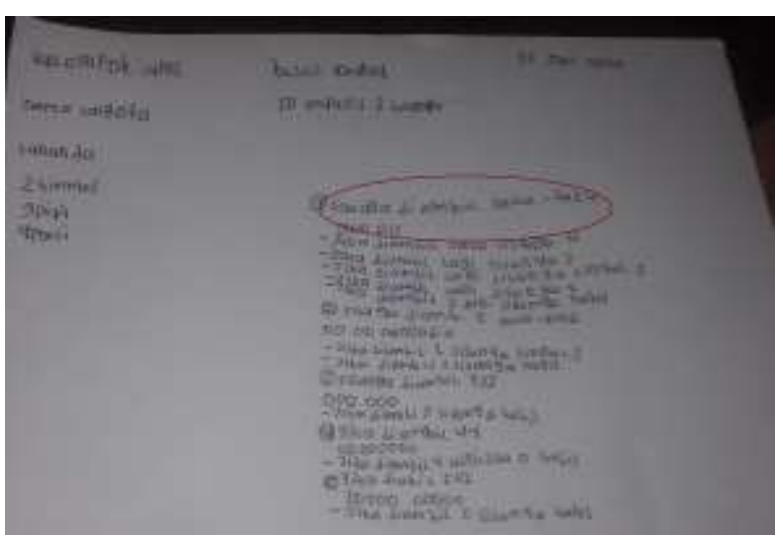

Gambar 8. Strategi kelompok apel menjawab soal LKS 2

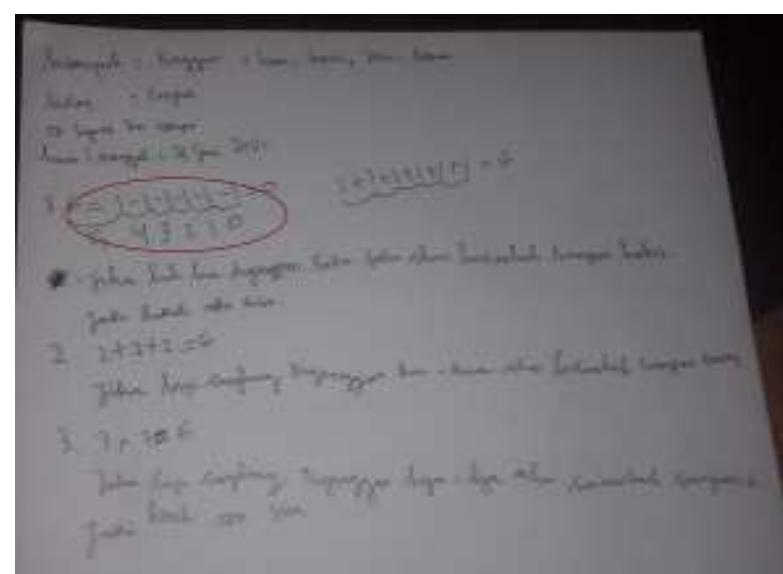

Gambar 9. Strategi kelompok anggur menjawab soal LKS 2

\section{Aktivitas 3 : mempresentasikan hasil diskusi}

Aktivitas hari ketiga dimana siswa akang mempresentasikan hasil diskusi mereka dengan bantuan guru.

Hasil kerja LKS 1 kelompok apel terlihat pada awalnya menganggap setiap aturan pengambilan mempunyai sisa pengambilan terakhir yang sama yaitu nol. Untuk mendapatkan sisa pengambilan terakhir nol, kelompok menambah jumlah biji cangkang yang dimainkan sehingga mendapatkan sisa pengambilan terakhir yang nol. Hal ini tidak sesuai dengan aturan bermain dalam permainan Kuli bia.

Dengan demikian peneliti melihat bahwa kelompok sudah memahami aturan permainan Kuli bia yaitu setiap pengambilan dilakukan dengan mengambil jumlah biji cangkang yang sama dengan aturan pengambilan yang telah ditetapkan. Hal tersebut dapat dilihat pada gambar kelompok yang menggambarkan pengambilan satu-satu. Dapat didukung dengan cuplikan transkrip di bawah ini.

Siswa : Kalo katong ambe 1, sisa ada 4. Kalo ambe lai, sisa ada 3. Kalo ambe lai, akang sisa ada 2. Ambe lai ada dia pung sisa 1. Kalo ambe kombali lai akang abis. Kalo ada 4 biji lalu ambe 2 itu akang sisa ada 2. Kalo ambe 2, akang sisa 0. Kalo katong ambe akang sisa tiga-tiga. Kalo ambe 3, akang sisa ada 3. Kalo ambe 3, akang sisa 0. Kalo katonng ambe 5 kuli bia itu seng ada sisa lai.

Dari cuplikan presentasi di atas tampak bahwa kelompok apel dapat menjelaskan bagaimana sisa pengambilan terakhir jika bermain dengan 5 biji cangkang. $\mathrm{Hal}$ ini bertentangan dengan aturan permainan 
Kuli bia serta tujuan dari proses pembelajaran. Dalam LKSnya menuliskan sisa pengambilan terakhir pada setiap aturan pengambilan adalah nol serta tidak bermain dengan jumlah biji bekel yang sama untuk setiap aturan pengambilan.

Strategi penyelesaian LKS 1 pada kelompok anggur menggunakan konsep matematika formal yaitu konsep pengulangan berulang untuk menggambarkan proses pengambilan biji cangkang dan menentukan sisa biji cangkang pada pengambilan terakhir. Melalui strategi pada gambar 9, peneliti mempelajari bahwa permainan Kuli bia berperan dalam menstimulasi siswa untuk menemukan konsep pengurangan berulang secara formal yang kemudian dapat berkembang menjadi konsep pembagian.

Hal ini juga dapat didukung dengan cuplikan penjelasan kelompok anggur dalam presentasi.

Siswa : Ada 6 biji cangkang di tangan. Kalo 6 itu katong ambe 1, sisa 5. Ambe 1, sisa 4. Ambe 1, sisa 3. Ambe 1, siswa 2. Ambe 1 lai, sisa 1. Ambe kombali lai akang abis.

Siswa : Kalo ada 6 lalu ambe 2, akang ada sisa 4. Ambe 2, sisa 2, ambe 2 lai, akang abis.

Siswa : 6 ambe 3, sisa 3. 6 ambe 4.6 ambe 5 sisa 1.

Dengan demikian dapat disimpulkan bahwa kelompok anggur menggunakan strategi pengurangan berulang untuk menggambarkan pengambilan pada permainan Kuli bia. Selain itu, peneliti melihat bahwa telah terjadi diskusi matematis tentang konsep pengurangan yang digunakan oleh kelompok. Peneliti juga melihat bahwa telah terjadi proses matematisasi dalam benak siswa yaitu proses mengubah situasi pengambilan pada permainan Kuli bia kedalam bentuk pengurangan berulang.

Kelompok apel mempresentasikan strategi penyelesaian LKS 2 dengan cara menceritakan proses pengambilan yang dilakukan dan berapa saja biji cangkang yang digenggam disetiap pengambilan pada aturan pengambilan tertentu. Strategi siswa yang menggambarkan proses berpikir yang paling sederhana adalah strategi yang menceritakan banyaknya biji cangkang yang digenggam disetiap pengambilan pada aturan pengambilan tertentu. Peneliti mengatakan demikian karena siswa hanya menceritakan banyak biji cangkang yang digenggam disetiap pengambilan pada aturan pengambilan tertentu. Siswa tidak menggambarkan objek-objek tertentu untuk menggambarkan perubahan banyak biji cangkang yang digenggam disetiap pengambilan. Berdasarkan hal di atas dapat disimpulkan bahwa permainan Kuli bia mempunyai peran untuk menstimulasi siswa membuat cerita tentang banyak biji cangkang yang digenggam disetiap pengambilan pada aturan pengambilan tertentu. Cerita tersebut dapat menjadi langkah awal siswa untuk mencari konsep matematika yang digunakan untuk mencari banyak biji cangkang yang digenggam. Berikut ini adalah cuplikan percakapannya.

Biji cangkang yang katong dapa ada 6. Kalo ambe 1 itu masih lokol. Kalo ambe 1 lai itu su loko 2. Kalo ambe 1 lai itu loko 3 Ambe 1 lai itu beta su loko 4. Ambe kombali itu loko 5 dalang tangan. Kalo ambe 1 dari tana itu loko 6 samua

Kan ada 6 biji cangkang ini to. Kalo bt ambe 2 itu akang masi 2 dalam beta tangan. Kalo beta ambe 2 lai itu beta su loko 4. Kalo beta ambe 2 lai ulang itu beta loko 6 samua.

Dari cuplikan transkrip di atas, kelompok apel hanya menceritakan proses pengambilan yang dilakukan serta banyak biji cangkang yang digenggam disetiap pengambilan pada aturan pengambilan tertentu. Disamping itu, kalimat yang disusun oleh kelompok merupakan kalimat yang sederhana dan mudah dipahami. Peneliti mengatakan demikian karena tidak ada siswa yang bertanya mengenai hasil diskusi kelompok apel.

Strategi penyelesaian pada LKS 2 yang dimunculkan pada kelompok anggur adalah strategi penjumlahan berulang. Strategi penjumlahan berulang merupakan strategi yang tidak lagi menggunakan cerita untuk mendeskripsikan banyak biji cangkang yang digenggam disetiap pengambilan pada aturan pengambilan tertentu, melainkan menggunakan penjumlahan berulang untuk mendeskripsikan banyak biji cangkang yang digenggam tersebut. Peneliti melihat bahwa permainan Kuli bia memiliki peran untuk menstimulasi siswa untuk menemukan konsep penjumlahan berulang dalam menentukan banyak biji cangkang yang digenggam disetiap pengambilan pada aturan pengambilan tertentu. Konsep penjumlahan berulang tersebut dapat menjadi titik awal bagi siswa untuk menemukan konsep perkalian yang merupakan konsep awal dari konsep kelipatan. Berikut ini merupakan cuplikan percakapannya. Siswa : Kalo bt punya biji cangjkanng dalam tangan Cuma 1, lalu tamba 1 lai itu akang jawaban 2. Kalo 2 itu beta tamba 1 biji cangkang lai akang dapa 3. Su 3 dalam beta tangan ni kalo beta ambe 1 lai akang jumlah 4. 
4 tamba 1 dapa hasil 5. 5 tamba 1 akang dapa 6.

Jadi seng ada sisa.

Dalam presentasi kelompok apel, peneliti melihat bahwa telah terjadi diskusi matematis mengenai konsep penjumlahan berulang. Hal tersebut dapat dilihat saat kelompok menjelaskan banyak biji cangkang yang digenggam pada pengambilan satu-satu dengan cara menjelaskan penjumlahan berulang dari bilangan 1. Strategi dan presentasi kelompok apel merupakan langkah awal siswa untuk menemukan konsep matematika apa yang direpresentasikan sebagai perubahan banyak biji cangkang yang digenggam.

\section{Aktivitas 4 : Menemukan konsep faktor dan Kelipatan dalam konteks bermain Kuli bia}

Aktivitas ini dilakukan pada pembelajaran hari keempat dimana kedua kelompok kembali ketempat duduk masingmasing setelah mempresentasikan hasil kerja, guru akan membantu siswa dalam menemukan konsep faktor dan kelipatan berdasarkan model sendiri (model of). Berdasarkan strategi yang dikembangkan akan menjadi model for walaupun terdapat satu strategi penyelesaian (LKS 2 kelompok anggur) yang sudah berkembang menuju tahap formal. Guru memberi nama untuk biji cangkang yang harus diambil supaya pengambilan terakhir tidak bersisa dengan nama faktor. Walapun istilah faktor diberikan oleh guru, siswa tidak diberitahukan mengenai pengertian faktor dalam permainan Kuli bia. Siswa diberi kebebasan untuk mendefinisikan faktor dalam permainan Kuli bia dengan kata-katanya sendiri. Berikut adalah cuplikan percakapan guru dan siswa dalam mendefinisikan faktor.

$\begin{array}{lll}\text { Guru } & : \text { Dong tau faktor itu apa e } \\ \text { Siswa } & : \text { Bilangan yang seng ada sisa } \\ \text { Guru } & : \text { Batul, kalo yang laeng tau faktor } \\ & \text { kaseng } \\ \text { Siswa } & : \text { Bilangan genap } \\ \text { Guru } & : \text { Ada jawaban yang laeng kaseng. Kalo } \\ & \quad \text { katong barmaeng Kuli bia itu akang } \\ & \quad \text { macam apa? } \\ \text { Siswa } & : \text { Biji cangkang yang seng ada sisa kio } \\ \text { Guru } & : \text { Su batul sudah mar faktor sandiri itu } \\ & & \text { apa? } \\ \text { Siswa } & : \text { Ganjil deng genap } \\ \text { Guru } & : \text { Apa yang ganjil dengan genap ini ? } \\ \text { Siswa } & : \text { Bilangan ganjil dan bilangan genap } \\ \text { Guru } & : \text { Yang tadi seng ada sisa itu apa? } \\ \text { Siswa } & : \text { Pembagian yang seng ada siswa } \\ \text { Siswa } & : \text { Pengurangan yang seng ada siswa } \\ \text { Guru } & : \text { Kalo tadi katong maeng Kuli bia, itu }\end{array}$

$\begin{array}{cc} & \text { faktor k seng? } \\ \text { Siswa } & \text { Permainan yang seng ada sisa } \\ \text { Berdasarkan transkrip percakapan di } \\ \text { atas dapat disimpulkan bahwa siswa }\end{array}$ mendefinisikan faktor sebagai pembagian tidak bersisa. Sebagian besar pendapat yang muncul dari siswa merupakan pengertian faktor dalam konteks formal, bukan dalam konteks permainan Kuli bia.. Namun hal ini tidak menjadi permasalahan bagi peneliti. Walaupun siswa sudah dapat mendefinisikan faktor dalam konteks formal, peneliti tetap menerima pendapat siswa tersebut dan membiarkan pendapat tersebut ada dalam benak siswa sehingga peneliti tidak memaksa siswa untuk mendefinsikan faktor dalam Kuli bia.

Guru mencoba mengarahkan siswa untuk masuk kedalam konsep kelipatan dalam permainan Kuli bia dengan cara memainkan kembali permainan Kuli bia serta mengarahkan siswa untuk melihat perubahan jumlah biji cangkang yang digenggam disetiap pengambilan pada aturan pengambilang tertentu. Guru memainkan pengambilan satusatu, dua-dua, tiga-tiga serta mengarahkan siswa untuk mengamati jumlah biji cangkang yang digengga, disetiap penagmbilan. Setelah siswa melihat perubahan biji cangkang tersebut, guru menanyakan istilah yang digunakan untuk menyebut jumlah biji cangkang yang digenggam tersebut. Guru memberi kebebasan kepada siswa untuk mengemukakan pendapatnya. Tujuan guru memberi kebebasan tersebut adalah menggali konsep apa yang dipahami oleh siswa melalui pengamatan terhadap perubahan jumlah biji cangkang yang digenggam disetiap pengambilan pada aturan pengambilan tertentu. Guru dapat menggunakan konsep yang dipahami siswa tersebut sebagai titik awal untuk mengenalkan konsep kelipatan. Dari pendapat yang dikemukakan oleh siswa, peneliti melihat bahwa siswa masih menyebutkan konsep pembagian dan pengurangan sebagai konsep yang ada dibalik perubahan jumlah biji cangkang yang digenggam disetiap pengambilan pada aturan pengambilan tertentu. Berikut adalah percakapannya.

Guru : Dong tau ini akang nama apa?

Siswa : Biji cangkang

Guru : Tapi akang pung nama apa kalo katong ambe dua la ambe dua lai?

Siswa : Pembagian

Guru : Ada yang laeng?

Siswa : Pengurangan

Siswa : Pembagian yang seng ada sisa

Berdasarkan percakapan di atas 
belum ada siswa yang melihat bahwa jumlah biji cangkang yang digenggam tersebut merupakan kelipatan. Siswa masih menyebutkan konsep-konsep matematika yang sama dengan konsep yang disebutkan saat siswa mempelajarai konsep faktor. Melalui hal ini, peneliti mempelajari bahwa siswa mengira dalam permainan Kuli bia hanya ada konsep pembagian dan pengurangan. Siswa tidak memikirkan adanya konsep matematika lain yang ada dalam permainan Kuli bia. Oleh karena itu, guru mengarahkan siswa menggunakan hal-hal sebelumnya seperti garis bilangan. Hal tersebut dapat dilihat dari cuplikan percakapan dibawah ini.

Guru : Contoh pada garis bilangan. Ada 0, 2, 6 , 8, dan seterusnya. Ini bilangan apa?

Guru : Kalo $+2++2$ dan setrusnya?atau 2, 4, 6, 8. Bilangan apa?

Siswa : Loncatan

Guru : Benar loncatan, kalo dalam matematika akang nama apa?

Siswa : Bilangan loncat

Guru : Kalo dalam kelipatan akang nama apa?

Siswa : Kelipatan

Berdasarkan percakapan di atas nampak bahwa siswa melihat jumlah biji cangkang yang digenggam sebagai loncatan atau bilangan loncat. Walaupun istilah dari siswa tersebut merupakan istilah yang benar, guru tetap memberikan klarifikasi mengenai istilah yang akan dipakai selanjutnya yaitu kelipatan. Tujuan guru memberikan klarifikasi tersebut adalah memberi tahu siswa bahwa konsep matematika yang akan mereka pelajari bukan lagi konsep bilangan loncat melainkan konsep kelipatan. Dengan demikian, siswa tidak berpaku pada istilah yang telah mereka kenal sebelumnya.

Setelah siswa mengenal konsep kelipatan melalui permainan Kuli bia, pada pertemuan berikutnya siswa diajak untuk mencari kelipatan dari 6 tanpa menggunakan permainan Kuli bia. Siswa bekerja secara berpasangan dengan teman sebangkunya.

\section{Aktivitas 5 : Konsep Faktor dan kelipatan secara Formal}

Pada hari kelima setelah merumuskan pengertian faktor dalam permainan Kuli bia, pada pertemuan selanjutnya siswa diajak untuk menentukan faktor dari bilangan 12 dan 20 tanpa menggunakan permainan Kuli bia. Walaupun tidak menggunakan permainan bekel, siswa dibantu dengan menggunakan tabel sisa pengambilan. Siswa mengerjakan tabel sisa pengambilan secara berpasangan dengan teman sebangkunya. Dalam tabel sisa pengambilan, siswa diajak untuk mengisi berapa saja sisa pengambilan terahir pada setiap aturan pengambilan jika siswa bermain dengan 12 dan 20 biji cangkang. Karena menggunakan tabel sisa pengambilan, tidak terdapat variasi strategi dalam menentukan faktor dari 12 dan 20. Walaupun demikian, siswa menggunakan beberapa strategi untuk mengerjakan tabel sisa pembagian.

Pada kategori strategi menggunakan jari, siswa sudah menggunakan konsep pengurangan dalam menentukan sisa pengambilan terakhir. Siswa menggunakan jari untuk merepresentasikan konsep pengurangan tersebut. Sedangkan pada kategori menggunakan benda-benda serupa dengan biji cangkang, siswa menggunakan konsep himpunan dalam menentukan sisa pengambilan terakhir. Siswa membuat himpunan benda yang anggotanya sejumlah dengan aturan pengambilan, dan benda yang tidak termasuk dalam himpunan benda-benda tersebut dinamakan sisa pengambilan terakhir. Setelah mengerjakan tabel sisa pengambilan, siswa mengidentifikasi berapa banyak biji cangkang yang harus diambil supaya pengambilan tidak bersisa dan bersisa. Karena pada pertemuan sebelumnya, siswa sudah mengenal istilah faktor, maka pada pertemuan kedua siswa hanya diajak untuk merumuskan pengertian faktor secara formal. Yang dimaksud pengertian faktor secara formal adalah faktor sebagai bilangan yang habis membagi dan sisa pembagiannya adalah nol.

Sebelum siswa mengenal konsel kelipatan persekutuan, guru mengajak siswa untuk mengubah cara penulisan kelipatan dari 8 dan 9 dari bentuj perkalian menjadi bentuk mendatar. Selain itu, guru juga mengajak siswa untuk mengingat bahwa yang merupakan kelipatan dari 8 dan 9 adalah hasil perkalian antara 8 dan 9 dengan bilangan urut, bukan bentuk perkaliannya. Setelah itu siswa diajak untuk mengidentifikasi kelipatan yang sama dari 8 dan 9. Sebelum siswa mengenal konsep kelipatan persekutuan, guru mengajak siswa untuk mengubah cara penulisan kelipatan dari 8 dan 9 dari bentuk perkalian menjadi mendatar. Selain itu guru juga mengajak siswa untuk mnegingat bahwa yang merupakan kelipatan 8 dan 9 adalah hasil perkalian anatara 8 dan 9 dengan bilanagan urut, bukan bentuk perkaliannya. Setelah itu siswa diajak untuk mengidentifikasi kelipatan yang sama dari kelipatan 8 dan 9. Seperti pada konsep faktor 
persekutuan, siswa pun melingkari kelipatan yang sama dari kelipatan 8 dan 9 yaitu 72 . Kemudian guru menjelaskan bahwa masih ada kelipatan yang sama jika siswa meneruskan mencari kelipatan 8 dan 9 sampai bilangan yang lebih besar. Hal tersebut dilakukan agar siswa tidak hanya mengira kelipatan persekutuan dari 8 dan 9 adalah 72, melainkan ada bilangan yang lebih besar seperti 144. Setelah itu, guru memberikan kesempatan bagi siswa untuk memberi nama kelipatan yang sama tersebut. Terdapat beberapa pendapat yang muncul dari siswa. Hal ini dapat dilihat dari cuplikan percakapan berikut ini.

Guru : Lia disini (menunjuk angka 72). Ini katong biasa bilang apa?

Siswa : Kelipatan yang sama

Siswa : Kelipatan yang persektuan

Berdasarkan cuplikan percakapan diatas, nampak bahwa istilah kelipatan persekutuan muncul dari pendapat siswa sendiri. Peneliti melihat bahwa penyebab siswa dapat menyebutkan istilah kelipatan persekutuan adalah proses pembelajaran untuk menentukan faktor persekutuan sama dengan proses pembelajaran untuk menentukan kelipatan persekutuan sehingga siswa dapat mengadopsi istilah yang mereka temukan pada pertemuan yang lalu yaitu faktor persekutuan. Setelah menemukan istilah kelipatan persekutuan tersebut, siswa diajak untuk merumuskan pengertian kelipatan persekutuan. Karena istilah kelipatan persekutuan berasal dari siswa, maka siswa tidak mengalami kesulitan dalam merumuskan pengertian kelipatan persekutuan.

\section{Aktivitas 6 : Faktor Persekutuan terBesar (FPB) dan kelipatan persekutuan terKecil (KPK)}

Pada pertemuan hari keenam, siswa akan mempelajari konsep faktor persekutuan dan Faktor Persekutuan terBesar (FPB). Pada pertemuan kelima siswa sudah dikenalkan dengan istilah faktor persekutuan sehingga siswa tinggal merumuskan pengertian faktor persekutuan. Dalam merumuskan pengertian faktor persekutuan, guru memberi soal kepada siswa untuk menentukan faktor dari 12 dan 20. Melalui soal tersebut, guru mengingatkan siswa tentang istilah faktor persekutuan. Ternyata siswa masih mengingat istilah faktor persekutuan untuk bilangan yang sama dari faktor persekutuan. Walaupun demikian, guru tidak menanyakan pengertian faktor persekutuan kepada siswa. Setelah siswa mengerti apa yang dimaksud dengan faktor persekutuan, guru mengajak siswa untuk masuk kedalam konsep faktor persekutuan terbesar.

Setelah menemukan pengertian kelipatan persekutuan, guru mengajak siswa untuk menemukan konsep kelipatan persekutuan terkecil dengan cara memberikan soal kepada siswa. Dalam soal tersebut, siswa diajak untuk menentukan kelipatan persekutuan dari 3 dan 4. Dari alasan yang dikemukakan oleh siswa, peneliti melihat bahwa siswa sudah memahami mengapa bilangan 12, 24 dan 36 merupakan kelipatan persekutuan dari 3 dan 4. Siswa tidak hanya menebaknebak jawabannya namun memakai konsep kelipatan persekutuan yang telah ditemukan. Setelah mendapatkan alasan yang jelas tersebut, guru mengajak siswa untuk menentukan suatu istilah jika guru memilih bilangan 12 dari kelipatan persekutuan 3 dan 4 . Salah satu siswa berpendapat bahwa bilangan 12 tersebut dinamakan kelipatan persekutuan yang paling kecil. Kemudian guru pun memberikan klarifikasi bahwa pendapat tersebut tidak salah namun belum sempurna. Sehingga guru pun menyempurnakan istilah tersebut menjadi kelipatan persekutuan terkecil. Dengan demikian, siswa pun sudah menemukan konsep kelipatan, kelipatan persekutuan, kelipatan persekutuan terkecil.

Pada akhir proses pembelajaran diberikan juga tes hasil belajar, dan juga mengisi angket siswa terhadap pembelajaran deng konteks permainan Kuli bia dengan pembelajaran matematika realistik.

\section{Analisis Tinjauan (retrospective analysis)}

Setelah kegiatan pembelajaran berakhir, guru model (peneliti) dan observer berdiskusi untuk merefleksikan sejauh mana hasil implementasi dari desain pembelajaran yang telah dilaksanakan. Dari hasil diskusi antara observer dan guru, menyadari sungguh ada perbedaan kemampuan yang dimiliki masing-masing siswa sehingga harus membutuhkan penanganan yang berbeda pula. Ada siswa yang sudah mampu secara langsung 
menyelesaikan persoalan tanpa memerlukan bantuan, tetapi ada juga yang masih membutuhkan bimbingan dengan menggunakan alatperaga untuk membantu menyelesaian persoalan Namun secara keseluruhan proses pembelajaran kali ini dapat disimpulkan berhasil dan dimana dapat menanamkan konsep faktor dan kelipatan kepada siswa dengan cara yang menyenangkan dan dekat dengan siswa.

Hasil Learning Trajectory (LT) yang diperoleh dari HLT yang telah didesain dan telah diujicobakan pada tahap teaching experiment dapat dilihat pada gambar berikut ini :

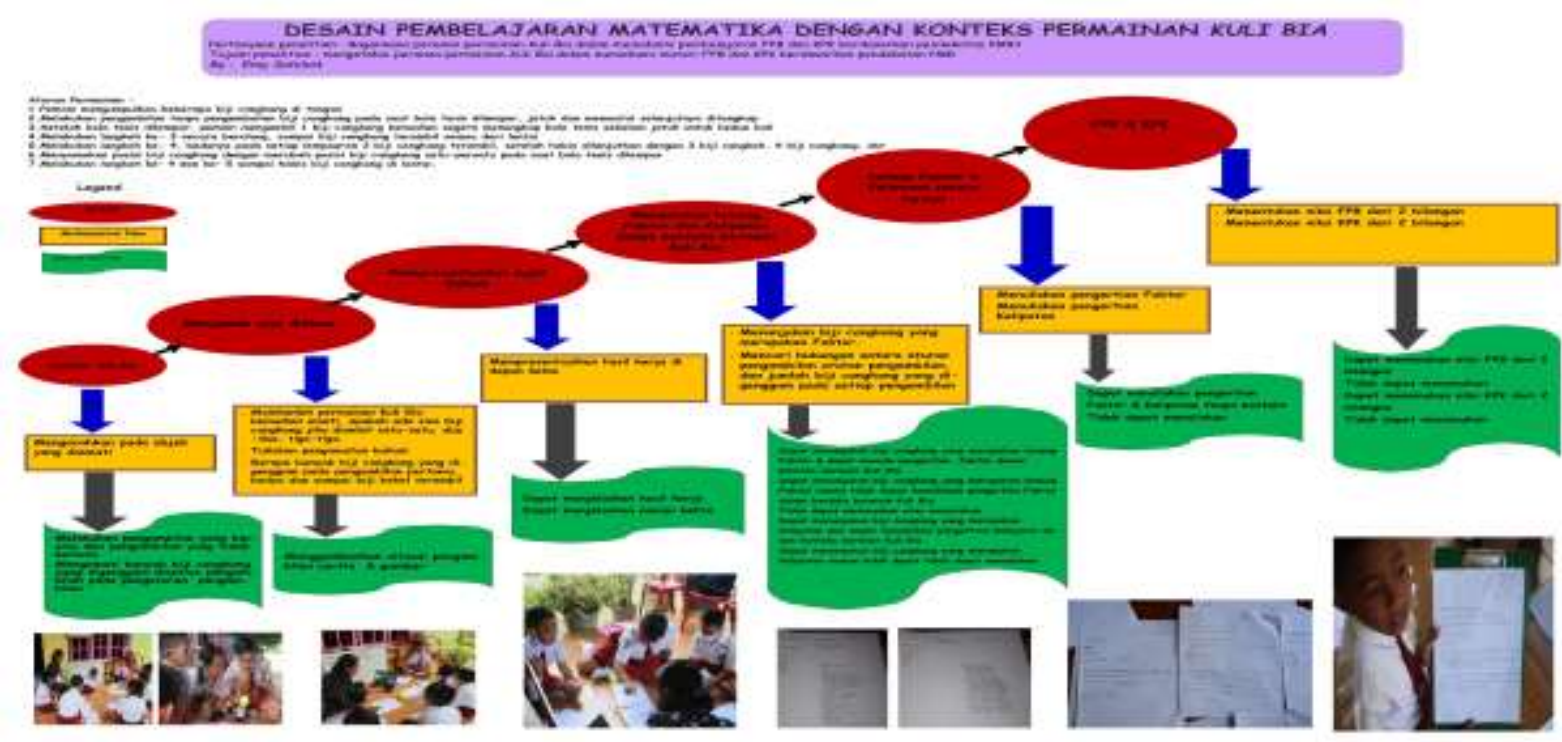

Gambar 10. Learning trajectory pembelajaran FPB dan KPK

Peneliti menganalisis data berupa tes hasil belajar, untuk mengukur kemampuan kognitif, lembar observasi pengelolaan pembelajaran, lembar observasi aktivitas belajar siswa, angket respon guru dan angket respon siswa pada tahap teaching experiment dan menggunakan hasil dari analisis untuk mengembangkan desain selanjutnya. Dapat ditunjukan dengan tabel berikut.

Tabel 1. Hasil data penelitian

\begin{tabular}{|c|l|l|l|}
\hline No & Data & Hasil & Kriteria \\
\hline 1. & $\begin{array}{l}\text { Rata-rata tes } \\
\text { hasil belajar }\end{array}$ & 82.6 & Tuntas \\
\hline 2. & $\begin{array}{l}\text { Rata-rata } \\
\text { aktivitas belajar } \\
\text { siswa }\end{array}$ & 4.1 & Baik \\
\hline 3. & $\begin{array}{l}\text { Rata-rata respon } \\
\text { siswa terhadap } \\
\text { pembelajaran }\end{array}$ & 4.6 & Senang \\
\hline 4. & $\begin{array}{l}\text { Rata-rata } \\
\text { pengelolaan } \\
\text { pembelajaran } \\
\text { guru }\end{array}$ & 4.3 & Baik \\
\hline
\end{tabular}

\begin{tabular}{|c|l|l|l|}
\hline 5. & $\begin{array}{l}\text { Rata-rata respon } \\
\text { guru terhadap } \\
\text { desain } \\
\text { pembelajaran }\end{array}$ & 3.97 & Baik \\
\hline 6. & $\begin{array}{l}\text { Rata-rata respon } \\
\text { guru terhadap } \\
\text { proses } \\
\text { pembelajaran }\end{array}$ & 4.17 & Baik \\
\hline
\end{tabular}

Secara keseluruhan desain

pembelajaran matematika dengan konteks permainan Kuli bia pada materi FPB dan KPK sudah berjalan dengan optimal. Hal tersebut dapat dilihat dari hasil tes prestasi belajar yang mendapatkan nilai rata-rata di atas KKM. Selain itu dapat dilihat dari aktivitas guru dan siswa yang menunjukkan kriteria baik. Respon guru dan siswa juga menunjukkan kriteria baik.

\section{Simpulan dan Saran Simpulan}

Pelaksanaan pembelajaran dengan konteks Kuli bia menggunakan pendekatan PMR pada materi Kuli bia pada kelas IV SD Inpres 2 Waipo berjalan optimal, respon siswa dan guru baik dan aktivitas guru dan siswa juga baik. Implementasi hypothetical learning trajectory memberikan peranan yang penting dalam mendukung siswa dalam melaksanakan pembelajaran FPB dan KPK dan meningkatkan motivasi siswa untuk belajar, meningkatkan 
prestasi belajar matematika pada materi FPB dan KPK. Memperoleh lintasan belajar (learning trajectory) pembelajaran FPB dan KPK.

Saran

Guru maupun peneliti hendaknya lebih memaksimalkan permainan tradisional di kabupaten Maluku Tengah sebagai titik awal pembelajaran (starting point) matematika. Dalam pembuatan desain dan perangkat pembelajaran hendaknya melakukan telaah dan diskusi yang melibatkan beberapa guru dan ahli yang berpengalaman.

\section{Ucapan Terima Kasih}

Penelitian ini terselanggara dari Dana Hibah Penelitian Dosen Pemula Anggaran Tahun 2020 oleh Deputi Bidang Penguatan Riset dan Pengembangan Kementerian Riset dan Teknologi/ Badan Riset dan Inovasi Nasional, berdasarkan SK Nomor 8/E1/KPT/ 2020 dan Perjanjian Nomor 06/P3MSP3/Peneliti/III/2020. Sehubungan dengan itu, kami menyampaikan terima kasih dan penghargaan setinggi-tingginya.

\section{Daftar Pustaka}

Bakker, A., Doorman, M., \& Drijvers, P. (2003). Design research on how IT may support the development of symbols and meaning in mathematics education. Onderwijs Research Dagen (ORD).

Bardsley, M. E. (2006). Pre-kindergarten teachers' use and understanding of hypothetical learning trajectories in mathematics education. Utrecht: University of Utrecht.

Bito, G. S. (2016). AKTIVITAS BERMAIN

SEBAGAI KONTEKS DALAM

BELAJAR MATEMATIKA DI

SEKOLAH DASAR DENGAN

PENDEKATAN MATEMATIKA

REALISTIK. Jurnal Pemikiran Dan

Pengembangan Sekolah Dasar (JP2SD), 250-255.

Daro, P., Mosher, F. A., \& Corcoran, T. B. (2011). Learning trajectories in mathematics: A foundation for standards, curriculum, assessment, and instruction. CPRE Research Reports.

Fuadiah, N. F. (2017). HYPOTHETICAL LEARNING TRAJECTORYPADA PEMBELAJARAN BILANGAN NEGATIF BERDASARKAN TEORI SITUASI DIDAKTIS DI SEKOLAH MENENGAH. Jurnal Mosharafa, 6(1), 13-24.

Hadi, S. (2006). ADAPTING EUROPEAN CURRICULUM MATERIALS FOR INDONESIAN SCHOOLS: A DESIGN OF LEARNING TRAJECTORY OF FRACTION IN ELEMENTARY EDUCATION MATHEMATICS. Banjarmasin: Lambung Mangkurat University, 1-9.

Haylock, D., \& Thangata, F. (2007). Key Concepts in Teaching Primary Mathematics (First). London: Sage Publication.

Sohilait, E. (2019). DESAIN

PEMBELAJARAN BERBASIS

PENDEKATAN PENDIDIKAN

MATEMATIKA REALISTIK DENGAN

MENGGUNAKAN MASALAH

KONTEKSTUAL. Prosiding Seminar

Nasional Pendidikan ....

Sugiman. (2011). Peningkatan Pembelajaran Matematika dengan Menggunakan Pendekatan Matematika Realistik. Jurusan Pendidikan Matematika FMIPA Universitas Negeri Yogyakarta, 1-12.

Surya, A., Zulkardi, Z., \& Somakim, S. (2017). Desain Pembelajaran Statistika Menggunakan Konteks Mal di Kelas V. Jurnal Elemen. https://doi.org/10.29408/jel.v3i2.344

Wijaya, A. (2009). Hypothetical Learning Trajectory dan Peningkatan Pemahaman Konsep Pengukuran Panjang. Seminar Nasional Matematika Dan Pendidikan Matematika. 